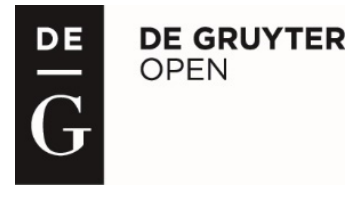

\title{
LEGE ARTIS
}

Language yesterday, today, tomorrow

Vol. II. No 12017

\section{AUTONOMOUS METACOMMUNICATIVE LEXICON AND ITS SPECIFICS IN MANIPULATIVE DISCOURSE}

\author{
Yaroslava Gnezdilova
}

Gnezdilova, Ya. Autonomous metacommunicative lexicon and its specifics in manipulative discourse // Lege artis. Language yesterday, today, tomorrow. The Journal of the University of SS Cyril and Methodius in Trnava. Warsaw: De Gruyter Open, 2017, vol. II(1), June 2017. p. 42-89. DOI: 10.1515/lart-2017-0002

\begin{abstract}
The article focuses on the study of metacommunicative means, and a unified approach to their classification is implemented. Special attention is drawn to distinguishing the main types of autonomous metacommunicative means and their functioning in manipulative discourse. The results show that the group of autonomous metacommunicative units comprises all those means, which preserve their metacommunicative functions even when other functions dominate.
\end{abstract}

Key words: metacommunication, metadiscourse, metacommunicative means, explicit / implicit metacommunicative devices, metalanguage / metatextual markers, manipulative discourse.

\section{Introduction}

Verbal communication is viewed as cognitive information exchange, and determines the existence of metacommunication, which assumes that special language means are used to regulate that exchange (Вежбицка 1978; Чхетиани 1987: 16). Metacommunication is realized in metadiscourse, where the regulation of verbal interaction is performed by means of metacommunicative items as its minimal lexical units. The latter represents a pragmaticalized class of expressive elements, used to regulate verbal interaction in various communicative contexts (Матюхина 2004).

Metacommunicative means (Андриановна 1991; Вежбицка 1978; Купряшкина 1991) have been the object of many research studies. Specifically, these units are well 
known as 'pragmatic particles' (Волкова 1987; Foolen 1996) or 'pragmatic items' (Богданова-Бегларян 2014), 'redundant words' (Yang \& Wilbur 1996), 'parasite words' (Кронгауз 2007: 34-35), 'empty words' (Cage 1981) or 'empty particles' (Земская 1983: 36), 'pause fillers' (Navarretta 2015; Yuan et al. 2016), 'parenthetic elements' (Ладыженская 1985), 'structural signals' (Ruth 2001: 1221), 'cohesive markers' (Coulthard 1981: 75; Hatch 1994: 223), and 'discourse markers' (Засєкін 2001; Зернецкий 1992: 70; Кронгауз 2001: 262; Archakis 2001; Fox Tree 2010; Fraser 1993; Kennedy 2000: 174-182; Kuo 1994; Lenk 1998; Risselada 1998; Schiffrin 1996; Torres 2002; Zarei 2013).

The most researched metacommunicative means are metacommunicative questions (Бондарик 2011; Гнезділова 2014b; Грабовська 2014; Стрельченко 2016; Чхетіані 1989, 1991), verbs (Kohnen 2012; Lopez Alvares 2005; Simon-Vanderbergen \& Defour 2012), markers (Пигрова 2001), or even such independently investigated metacommunicative elements as now (Taavitsainen \& Hiltunen 2012), oh, well (Baiat et al. 2013; Hum \& Hum, s.a.), you know, like, what I'm saying (Croucher 2004). With respect to the object of investigation, it varies from traditional genres (oral speech / discourse (Богданова 2012), written discourse (Dossena 2012; Fitzmaurice 2012)) to specific ones (argumentative discourse (Gotti 2012), computer-mediated discourse (Bublitz 2012), religious discourse (Кожинова 2011)). The aspects of investigation comprise communicative, functional, and pragmatic approaches to metadiscourse analysis. So, in the scope of a communicative approach, metacommunicative items are classified in accordance with conditions of investigation, categories of textual organization, content orientation, and evaluation, and the manner of expression, code and intention (Пигрова 2001). In terms of functional approach, metacommunicative items are introduced as discourse organizers and / or regulators of verbal interaction (Гнезділова 2014a; Синицына 2005; Hübler \& Busse 2012: 2-3). Regarding a pragmatic approach, communicative maxims are studied (Brock 2012), or such special cases as civilized belligerence (Verschueren 2012), hoaxing (Heyd 2012) are 
considered. Within speech act theory it is a question of perlocutionary optimizers (intensifiers and mitigators) in the phatic speech act (Криворучко 2011: 9-12).

However, according to Sinitsyna (Синицына 2005), a generalizing analysis of metacommunicative devices has not been among the priorities in linguistics. In other words, the lack of a unified approach to their classification is partly due to the fact that empirical research studies are normally focused exclusively on one or on a few metacommunicative markers. Moreover, the majority of these devices, discussed in the aforementioned studies, belong to the group of autonomous metacommunicative devices, which are the objective of the present study.

\section{Methodology and theoretical framework}

The objective of this article is achieved by fulfilling the following tasks: (i) to outline the classification of various metacommunicative units; (ii) to systematize metacommunicative units, which belong to the group of autonomous ones; and (iii) to study their specific use in manipulative discourse. To reach the objective of the research and accomplish its tasks, a number of general scientific methods (deduction, induction, analysis, and synthesis) as well as methods of linguistic analysis (pragmatic, discourse, and contextual analyses) are used.

The research corpus comprises different genres discourse, with a specific focus on everyday communicative situations and instances of public speaking, predominantly selected from popular American movies (The Wedding Crashers (2005), S1mOne (2002), The Big Bang Theory (2007)) and prominent speeches (Mary Fisher "A Whisper of AIDS" (1992); Pope Benedict XVI "In this place of honor" (2006); J.K. Rowling "The Fringe Benefits of Failure, and the Importance of Imagination" (2008)).

At the outset of my research, I hypothesized that there should be some specific metacommunicative items for these opposite discourse types. In my view, it would not be very true to say now that there is no difference in the use of metacommunicative 
items in 'everyday' dialogues and public monologues, but this dissimilarity is imposed on them by the style of speech and by communicative tradition, in accordance with which either of the discourse is built. In fact, it is absolutely possible, under certain conditions, to use any metacommunicative item of any group in both discourse types, which is proved by the examples used to illustrate the theoretical points.

It should also be indicated that the object of investigation is metacommunicative units, not manipulative discourse. That is why the focus of the research is on the use of metacommunicative units in manipulative discourse rather than its definition, background studies, classification etc. Yet, some specifics in the use of metacommunicative items in manipulative situations, as compared to nonmanipulative situations, are underlined.

My research is grounded in the fundamental work of Hübler and Busse (2012). Their idea to analyze metacommunicative means on the assumption of the metapragmatic awareness of people is further developed in this article.

According to Hübler and Busse (2012), metapragmatic awareness is indicated by metacommunicative lexicon, which is generated when people become aware of their actions during interaction and desire to share details with others. This metapragmatic awareness, which stimulates the emergence of particular linguistic means, can be realized in three ways:

a) explicitly reflecting everything that happens in current communication. While accompaning main communication, metacommunication only refers to some communicative events in current communication when its certain aspects are transformed into the theme of the sentence / discourse, or are endued with a metacommunicative function;

в) abstracting from interactive and conceptually construed communication models when meaningful lexemes, marking the form of communication or its aspects, can 
function only metacommunicatively: their metacommunicative usage turns them into metacommunicative expressions;

c) transforming metapragmatic awareness into corresponding communicative behavior.

Metacommunicative units, which emerge in accordance with the first two points, are formed by synthesizing inner aspects of communication and fall into two groups: autonomous and contextually dependent metacommunicative units. Unlike the aforementioned metacommunicative units, expressions, which emerge as a result of the third way of their formation, mark the communicative characteristics which are imposed on the communication externally. Here I speak of metacommunicative indicators as genre triggers (see Fig. 1).

\section{METACOMMUNICATIVE UNITS}

SYNTHESIZE INNER ASPECTS OF COMMUNICATION

autonomous metacommunicative units contextually-dependent metacommunicative units
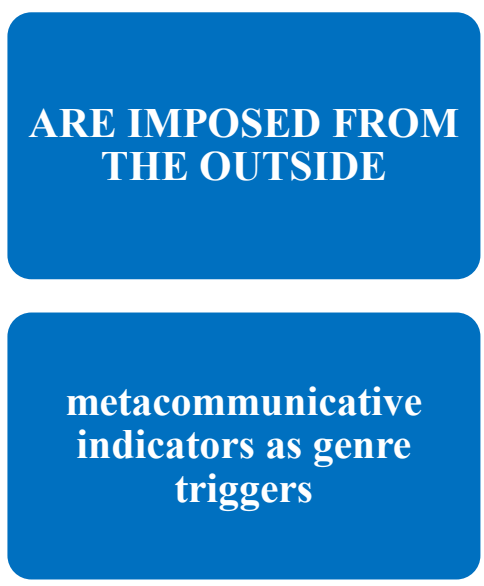

Figure 1. The classification of metacommunicative lexicon

The focus of this article is on the group of autonomous metacommunicative units only, and they are analyzed and discussed below. 


\section{Autonomous metacommunicative units}

Metacommunicative units are one of the most analyzed questions in the field of pragmatics. According to Aryukhina (Арюхина 2006), Pigrova (Пигрова 2001), Sinitsyna (Синицына 2005) these units arrange and carry on the dynamics of interaction / discourse, and are rather conventionalized utterances of contacting and regulating nature. Their purpose is to start, continue, or finish verbal interaction, check the communication channel, draw an interlocutor's attention, and make sure that he / she is a keen listener. In fact, there is no absolutely autonomous metacommunicative lexicon, for metacommunicative function is not the only function of these items. Yet, purely metacommunicative are style disjuncts, e.g., Frankly speaking, I'm fed up, I was virtually transfigured; reformulatory or replacive conjuncts, e.g., In other words, I don't like it; discourse-transitional conjuncts, e.g., Frankly, By the way, I feel thirsty (in terms of Hübler \& Busse, 2012: 2-3); interjections, e.g., oh, well, hey, which also include curses like damn you, dammit and oaths like my God, for God's sake, Oh my God, Dear God. However, this group of metacommunicative units should not be limited to those, mentioned above. All metacommunicative units, which preserve their metacommunicative function with a change of context, belong, in my view, to the group of autonomous units, irrespective of the fact that they can possibly perform functions other than metacommunicative.

Autonomous metacommunicative units, as I call them, differ in structure and complexity: from an utterance / a number of utterances, with certain lexeme / lexemes in the centre constituting the communicative concept, to simple particles (Hübler \& Busse 2012: 2-3). Pigrova (Пигрова 2001) and Kryvoruchko (Криворучко 2011: 912) claim that these units may be of two types: explicit expanded expressions, or explicit metacommunicative devices, as I call them; and implicit word-groups, or metacommunicative markers. The boundary between explicit metacommunicative devices and markers is vague, as criteria of their differentiation (the size of expressions, their frequency, opacity of their meanings, and the degree of disruption of morphological relations (Пигрова 2001)) are sometimes indistinct. Therefore, the 
solution may be to use syntactic complexity and independence as a criterion for these two groups of units. Thus, independent structures, i.e., sentences used metacommunicatively, belong to explicit metacommunicative devices; and dependent structures, i.e., word-groups and separate words used metacommunicatevily, constitute a group of markers. These units are further subdivided into various types, as shown in Figure 2.

\section{AUTONOMOUS METACOMMUNICATIVE UNITS}

IMPLICIT WORD-COMBINATIONS,

OR METACOMMUNICATIVE MARKERS

METALANGUAGE

MARKERS

-speech organizers

-means of approximate nomination

-interaction regulators
METATEXTUAL

MARKERS

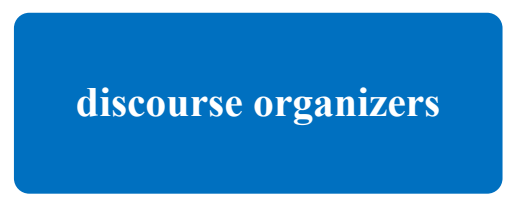

EXPLICIT

METACOMMUNICATIVE DEVICES

-declaratives

-interrogatives

-imperatives

Figure 2. The classification of autonomous metacommunicative units

An analysis of these structures is provided below.

\subsection{Explicit metacommunicative devices}

As noted above, explicit metacommunicative devices or "perlocutionary optimizers" in the terms of Kryvoruchko (Криворучко 2011: 9-12) are declarative, interrogative, and imperative sentences, or declaratives, interrogatives, and imperatives, respectively. The main feature of all structures of this group, as I see it, is that they are not propositionally but sociatively meaningful. Therefore, instead of providing or obtaining 'lacking' information, or confirming / denying their statement, they express indirect imposition to maintain verbal contact. The function of these metacommunicative means is in additional nomination of questions or imposition, 
elucidation of the utterance intention, intensification of the perlocutionary effect. Moreover, the meaning and their effect can be strengthened if (i) declaratives, interrogatives, and imperatives are turned into exlamatives or (ii) these structures are combined, e.g., "declarative+interrogative", "declarative+imperative", "declarative+ interrogative", "interrogative+imperative".

\subsubsection{Declaratives}

Declaratives, used as metacommunicative units, are, in my view, a bit problematic. Notably, a metacommunicative interpretation of declaratives might be debatable even in obvious metacommunicative contexts. That is why, a set of features, which prove the metacommunicative nature of declaratives, has been identified. First, it is a shift from the main information to the accompanying one, which creates a slight deviation from the topic. It is important, especially in manipulative discourse, when the speaker wants the interlocutor to link the main information to the accompanying, and, accordingly, make him / her come to some particular conclusions; or intends to emphasize and develop that very 'link'. Also importantly, it is the creation of, in terms of Ushchyna (Ущина 2015), a "metacommunicative situation", where the speaker speaks as an outsider, making his / her own comments on the situation alongside shifting responsibility; or transfers his / her experience to the interlocutor, programming his / her behaviour; or predicts a hypothetical situation.

As follows, when declaratives are used metacommunicatively, the speaker:

1) describes his / her actions, e.g., Now all I have to do is take deep breaths, squint at the red banners and convince myself that I am at the world's largest Gryffindor reunion; or his / her intentions, or the intentions of the recipient, e.g., I would like to make it clear ...; I am not going to stand here and tell you that ...; ... and began to direct all my energy into;

2) depicts (i) real situation in which the similar speech action is / has been realized, e.g., Not only has Harvard given me an extraordinary honour, but the weeks of fear and nausea I have endured at the thought of giving this commencement address have 
made me lose weight; (ii) possible and / or desirable situation, e.g., the fact that you are graduating from Harvard suggests that you are not very well-acquainted with failure; (iii) past situation, actions / thoughts of the speaker at that moment of speaking, e.g., That period of my life was a dark one, and I had no idea that there was going to be what...; I had no idea then how far the tunnel extended, and for a long time, any light at the end of it was a hope rather than a reality; And so rock bottom became the solid foundation on which I rebuilt my life;

3) changes and modifies basic, propositional modality expressing the modal position of the speaker (see Арюхина 2006) via modal verbs that influence the modality of the main utterance, e.g., This liberating discovery enables me to proceed without any fear. that I might inadvertently influence you to abandon; I cannot criticize my parents for hoping; You might be driven by; your conception of failure might not be too far from; Had I really succeeded at anything else, I might never have found the determination to succeed in the one arena; You might never fail on the scale I did; One might use such an ability to manipulate; They can refuse to hear screams or to peer inside cages; they can close their minds and hearts to any suffering that does not touch them personally; they can refuse to know; I might be tempted to envy people who can live that way; I can and must echo his words;

4) avoids responsibility via passives, e.g., They were seen as part of the refuse of world history; The Germans who had been brought to Auschwitz-Birkenau and met their death here were considered as Abschaum der Nation - the refuse of the nation); 5) specifies or dispels an interlocutor's attention via parenthetic constructions, especially in the form of conditional or restricting clauses, e.g., At your age, in spite of a distinct lack of motivation at university, where I had spent far too long in the coffee bar writing stories, and far too little time at lectures, I had a knack for passing examinations, and that, for years, had been the measure of success in my life and that of my peers; This liberating discovery enables me to proceed without any fear that I might inadvertently influence you to abandon promising careers in business, the law or politics for the giddy delights of becoming a gay wizard; I would like to make it clear, in parenthesis, that I do not blame my parents for their point of view; What is 
more, I cannot criticize my parents for hoping that I would never experience poverty; Such knowledge is a true gift, for all that it is painfully won, and it has been worth more than any qualification I ever earned;

6) uses, in terms of Austin, constatives (1962, as cited in López Álvarez 2005: 685686), the metacommunicativity of which is realized via ascertaining the facts or describing the surrounding world in the form of short sentences with a background of complicated utterances. Constatives may become parts of composite sentences but their expressive effect, then, is less. As a result, such sentences are either introductory or summarizing structures, which accumulate the listener's attention, e.g., Delivering a commencement address is a great responsibility; Some failure in life is inevitable; Life is difficult, and complicated).

To sum up, I would like to state that the afore-discussed theoretical points are true about the manipulative discourse, and illustrate some of them with examples 1-2, stressing the effect they create in the context:

(1) Secretary Cleary approaches with Gloria and his wife.

SEC. CLEARY: There you two are.

JEREMY: Actually ... we're about to leave. It's been a lovely wedding. (to Gloria) I'll call you. It's a promise.

SEC. CLEARY (ignoring Jeremy, to John): Well, look, we always hate to see the wedding end so we keep the party going back at our little place on the Vineyard. It's sort of a Cleary family tradition. And, well, since we've all taken a shine to you, we'd love you to be our guests for the weekend. What do you say?

Gloria smiles hopefully. Kathleen Cleary does the same. Claire and Sack approach the group. John looks at Claire.

JOHN: We'd love to.

JEREMY: What?! We don't have any other clothes!

SEC. CLEARY: Oh, we have everything you need out on the island.

JEREMY: But I promised my Granny I'd take her to the park.

GLORIA: And I'm sure daddy can hire somebody to take your Granny to the park. 
SEC. CLEARY: Not a problem.

JOHN: Great! Done. ("The wedding crashers").

Example 1 shows the situation, which is manipulative for Jeremy: he feels as if he is in a trap, because he finds his relations with Gloria dangerous and alarming, so he wants to escape. The manipulator is Gloria who made her father Secretary Cleary invite the young men. Secretary Cleary was pleasantly impressed with John, therefore, he insists on their coming. John wants to go and have a chance to woo Claire, for that reason he does not pay attention to what happened to his friend. Their conversation might be referred to as metacommunicative overall, since it consists of an invitation, false excuses and the acceptance of the invitation. Jeremy describes their intentions (Actually ... we're about to leave), makes a complement (It's been a lovely wedding) and a promise to Gloria (I'll call you). Not allowing Gloria to feel that he was not going to follow that promise, he uses a constative (It's a promise). Secretary Cleary explains their plans, depicting the current situation (Well, look, we always hate to see the wedding end so we keep the party going back at our little place on the Vineyard) and the desirable one (we'd love you to be our guests). He distracts John's attention via a compliment, expressed by a parenthetic clause (since we've all taken a shine to you).

(2) You might never fail on the scale I did, but some failure in life is inevitable. It $\underline{\text { is }}$ impossible to live without failing at something, unless you live so cautiously that you might as well not have lived at all - in which case, you fail by default. (Rowling 2008) In this excerpt of Rowling's influential speech, one of the metacommunicative means is the modal verb (might), and expression (is impossible), which help the speaker create a hypothetical situation for the audience on the basis of her own experience. Due to the constative, which is the part of the composite sentence (some failure in life is inevitable), she introduces and programs the idea that one should not be afraid to live, since, in any case, all people fail in something. 


\subsubsection{Interrogatives}

In the field of pragmatic studies, interrogatives have been rather well-analyzed in a number of research works (Арюхина 2006; Бондарик 2011; Гедз 1998; Грабовська 2014; Малюга 2001; Стрельченко 2016; Чхетиани 1987, 1989, 1991). These are often used not in their direct meaning and function. In this matter, Chkhetiani speaks of communicative and metacommunicative questions within the theory of phatic metacommunication (Чхетиани 1987: 100-102). Communicative questions are aimed at eliminating information deficits, that is, when the speaker asks for the information he / she lacks in the form of general, special, alternative or disjunctive questions. Metacommunicative questions express indirect incentives to maintain verbal contact whilst activating the interlocutor's reactive activity, which is manifested via the close attention of the listener to the speaker. Metacommunicative questions are aimed at establishing, maintaining, and terminating speech contact and, on this basis, Chkhetiani (Чхетиани 1987) and her adherent Hrabovska (Грабовська 2014) classified them into:

a) contact-establishing questions or attention-getting questions: questionsgreetings, questions-identifications, questions-pleonasms, questions-appeals, questions-addresses, questions-compliments, questions-offers, questionstopicalizators;

b) contact-maintaining questions of the speaker: rhetoric questions, reflexive questions, affixal / disjunctive questions, autocentric questions, intriguing questions, controlling questions; and contact-maintaining questions of the hearer: echo questions, verifying questions;

c) contact-terminating questions: questions-expectations, questions-invitations, questions-excuses.

Metacommunicative questions were thoroughly described in one of my prior publications. That is why here, I illustrate their specific use in manipulative contexts only. Consider examples 3 and 4 :

(3) SACK: No, I'll be fine. So, John, where'd you say you guys were from up there in New Hampshire?

JOHN: I didn't. But we're from Manchester. 
SACK: Great town.

JOHN: Big city with a small town heart.

SACK: A college buddy of mine moved up to Manchester. He loves the place. Maybe you know him; Skunk Baker?

JOHN: Sorry. Big city. Small town heart. But still a big city. [...]

SACK: You sure you don't know Skunk? He's the big guy with Chase up there. Surely in your line, you've come across each other ("The wedding crashers").

The task of Sack in example 3 is to prove that John is a liar. So he asks provocative metacommunicative questions (see underscored elements) which are aimed at checking his interlocutor. John answers with very brief sentences - too brief to be just explained by the rule of economy of speech efforts in oral speech. In this particular case John follows the tactics: the less words, the more chances not to be caught on lie. Sack even uses an echo question (You sure you don't know Skunk?) irrespective of the fact that these questions are normally used by listeners. In manipulative discourse echo questions, verifying questions may be used by speakers to check the listener's attention, attitude, or reaction to the message.

(4) We may take refuge in our stereotypes, but we cannot hide there long, because HIV asks only one thing of those it attacks. Are you human? And this is the right question. Are you human? Because people with HIV have not entered some alien state of being. They are human. They have not earned cruelty, and they do not deserve meanness. They don't benefit from being isolated or treated as outcasts. Each of them is exactly what God made: a person; not evil, deserving of our judgment; not victims, longing for our pity people, ready for support and worthy of compassion (Fisher 1992).

In example 4 Mary Fisher uses one contact maintaining question Are you human? in two different meanings. In the first case, it is a rhetorical question, in the second - an echo question, used by the speaker (see explanations above, given to example 3). As a result, rhetorical and echo questions add expressivity to the speech, especially in combination with answers which are not obligatory, since they are easily understood from the context. 


\subsubsection{Imperatives}

Imperatives are not as well-researched as interrogatives. It might be due to the fact that imperatives express imposition and that is their direct propositional meaning. In metacommunicative contexts, imposition should be minimized by indirect structures, e.g., via questions, hints etc. Thus, it would be wrong to state that imperatives are not used metacommunicatively. Imperative structures, when used to increase the expressive effect of the message in the form of slogans, turn into metacommunicative. Such imperatives are widely-used in influential speeches, as illustrated in example 5: (5) [...] No - when all is said and done, we must continue to cry out humbly yet insistently to God: Rouse yourself! Do not forget mankind, your creature! And our cry to God must also be a cry that pierces our very heart, a cry that awakens within us God's hidden presence - so that his power, the power he has planted in our hearts, will not be buried or choked within us by the mire of selfishness, pusillanimity, indifference or opportunism. Let us cry out to God, with all our hearts, at the present hour, when new misfortunes befall us, when all the forces of darkness seem to issue anew from human hearts: whether it is the abuse of God's name as a means of justifying senseless violence against innocent persons, or the cynicism which refuses to acknowledge God and ridicules faith in him. Let us cry out to God, that he may draw men and women to conversion and help them to see that violence does not bring peace, but only generates more violence - a morass of devastation in which everyone is ultimately the loser. [...] (Pope Benedict XVI 2006)

Example 5 clearly demonstrates that direct imperatives (Rouse yourself! Do not forget mankind, your creature!) are used here as intensifiers of "we must continue to cry out", which precedes them, and "our cry to God", which follows. The word-combination "our cry to God" is repeated in parallel imperatives, the imposition of which is somewhat softened with Let-structures. In any case, the expressive usage of all those imperatives proves that they have turned into metacommunicative. 


\subsubsection{Combined structures}

As the analysis shows, declaratives, interrogatives, and imperatives can combine forming some blocks, which are highly effective ways of expressing and creating climax in planned discourse, including manipulative. Their main function is to motivate, prompt, impose, or provoke the interlocutor to some particular behaviour desirable to the speaker. Such blocks may be of two types:

1) blocks of similar structures like "declarative+declarative", "imperative+imperative", "interrogative+interrogative";

2) blocks of various structures like "declarative+interrogative", "declarative+imperative", "declarative+interrogative", "interrogative+imperative". These two types of blocks are illustrated in example 8:

(6) How many questions arise in this place! Constantly the question comes up: Where was God in those days? Why was he silent? How could he permit this endless slaughter, this triumph of evil? The words of Psalm 44 come to mind, Israel's lament for its woes: "You have broken us in the haunt of jackals, and covered us with deep darkness ... because of you we are being killed all day long, and accounted as sheep for the slaughter. Rouse yourself! Why do you sleep, O Lord? Awake, do not cast us off forever! Why do you hide your face? Why do you forget our affliction and oppression? For we sink down to the dust; our bodies cling to the ground. Rise up, come to our help! Redeem us for the sake of your steadfast love! " (Ps 44:19, 22-26). This cry of anguish, which Israel raised to God in its suffering, at moments of deep distress, is also the cry for help raised by all those who in every age - yesterday, today and tomorrow - suffer for the love of God, for the love of truth and goodness. How many they are, even in our own day! (Pope Benedict XVI 2006)

Example 8 presents two blocks of similar structures: "interrogative+interrogative" (Where was God in those days? Why was he silent? How could he permit this endless slaughter, this triumph of evil?) and "imperative+imperative" (Rise up, come to our help! Redeem us for the sake of your steadfast love!); and one block of various structures "interrogative+imperative" (Rouse yourself! Why do you sleep, O Lord? 
Awake, do not cast us off forever! Why do you hide your face? Why do you forget our affliction and oppression?). The expressive effect is additionally increased via exclamations and message framing with the declarative-constative How many questions arise in this place! This speech has a great impact on people's emotions; moreover, emotions are programmed by the speaker.

To sum up, I would like to say that declaratives, interrogatives, and imperatives as explicit metacommunicative devices are used for the additional accentualization of some events / words / actions of the speaker, irrespective of the type of discourse. When these devices are combined or turned into exclamatives, they happen to be an effective tool used to intensify the perlocutionary effect of the utterance. The only peculiarity I have come across while studying the use of the aforementioned devices in manipulative discourse, concerns interrogatives, namely echo questions and verifying questions, used by speakers (not listeners) to check the listener's attention, attitude, or reaction to the message.

\subsection{Metacommunicative markers}

The analysis of metacommunicative markers in current study is grounded in Pigrova's framework (Пигрова 2001), where they are viewed as specific indicators, employed by the speaker to convey the most frequently used meaning in the most minimized way. Notably, they are more efficient, when compared to explicit metacommunicative devices. In her study, Pigrova (Пигрова 2001) organizes metacommunicative markers into two groups: (i) metalanguage markers and (ii) metatextual markers.

Overall, metalanguage markers are 'content-oriented' as the main function they perform is to organize and regulate interaction / speech in accordance with Grice (1975) interaction postulates. Metatextual markers are 'structure-oriented' as they are responsible for discourse cohesion and coherence. Moreover, the position of markers in the utterance may be significant in creating its perlocutionary effect. 


\subsubsection{Metalanguage markers}

Metalanguage markers or metaoperators (in terms of Aryukhina (Арюхина 2006), additionally nominate the head act, verbalizing the speaker- / listener-oriented action. The relationship between a metalanguage marker and the head act are characterized as subordinative. The propositional and core content is in the head act, while the metalanguage marker services it, either intensifying or softening intentions embedded in it, thus performing an additional function. As I see it, metalanguage markers can be further subdivided into: (i) speech organizers; (ii) approximate nomination devices; and (iii) interaction regulators.

Speech organizers, depending on the phase of speech contact, perform different functions and can be categorized into:

(i) contact-establishing markers, e.g., greetings (e.g., Hi; welcome to; Good morning), congratulations (e.g., Congratulations to); words of address, which together with neutral units (e.g., President Faust, members of the Harvard Corporation and the Board of Overseers, members of the faculty, proud parents, and graduates; Harvard graduates of 2008) can perform emotional and evaluative functions via lexical units with both positive (e.g., sonny; my boy; daddy) and negative connotations (e.g., you bastard; stupid; old girl; devil; damned fool);

(ii) contact-maintaining markers, e.g., gratitudes (e.g., thank you; thank-you very much; with profound respect and gratitude); excuses (e.g., We don't mean to interrupt...); encouragements (e.g., Well?; So?);

(iii) contact-terminating markers, e.g., blesses and wishes (e.g., God bless the children, and God bless us all; I wish you nothing better than; I wish you all very good lives), partings (e.g., Good night; Bye).

Speech-organizing markers are illustrated in example 7:

(7) Leonard: New neighbour?

Sheldon: Evidently.

Leonard: Significant improvement over the old neighbour.

Sheldon: Two hundred pound transvestite with a skin condition, yes she is. 
Penny: Oh, hi!

Leonard: $\mathrm{Hi}$.

Sheldon: $\mathrm{Hi}$.

Leonard: Hi.

Sheldon: Hi.

Penny: Hi?

Leonard: We don't mean to interrupt, we live across the hall.

Penny: Oh, that's nice.

Leonard: Oh... uh... no... we don't live together... um... we live together but in separate, heterosexual bedrooms.

Penny: Oh, okay, well, guess I'm your new neighbour, Penny.

Leonard: Leonard, Sheldon.

Penny: Hi.

Leonard: Hi.

Sheldon: Hi.

Penny: Hi.

Leonard: Hi. Well, uh, oh, welcome to the building.

Penny: Thank you, maybe we can have coffee sometime.

Leonard: Oh, great.

Penny: Great.

Sheldon: Great.

Leonard: Great. Well, bye.

Penny: Bye.

Sheldon: Bye.

Leonard: Bye. ("The big bang theory").

Example 7 demonstrates the use of contact-establishing markers (e.g., $\mathrm{Hi}$ ), contactmaintaining markers (e.g., We don't mean to interrupt, we live across the hall; Oh, that's nice; Oh, okay, well, guess I'm your new neighbour, Penny; Well, uh, oh, welcome to the building; Thank you, maybe we can have coffee sometime; Great) and 
contact-terminating markers (e.g., Bye). In this example, Leonard and Sheldon are getting acquainted with their new neighbour Penny. Interestingly, their conversation contains exclusively metacommunicative units. Though they belong to the intellectual elite, in everyday situations they lack confidence, which is demonstrated by frequent repetitions of $\mathrm{Hi}$, Great, Bye, pauses, and pause-fillers $O h \ldots$ uh... no... um ...., Penny's response $H i$ ? proves that this situation can be perceived as odd.

With respect to speech organizing markers, two specific features should be considered in manipulative discourse. The first concerns the 'stylistic' devices used to design a particular utterance. If the speaker needs to gain the favour of the interlocutor irrespective of the speaker's real attitude towards the latter, very polite positive devices are used. However, if the speaker needs to get rid of the interlocutor or make the latter think badly of someone, devices with a negative connotation are employed. The second feature is linked to the number of devices used by the speaker: when the speaker 'bombards' the interlocutor mostly with contact-establishing and contact-maintaining markers in order to impress him / her.

The reasons for manipulation can be various, which leads to the employment of various strategies. However, they have a common aspect: the use of speech-organizing markers which hide the true motive of their use. I would like to illustrate it with examples.

The examples given below describe a meeting of cast members (Hal, Lotus, Mac and three other) in a new movie "ETERNITY FOREVER" directed by Viktor Taransky with Simone as the lead. The manipulator here is Viktor Taransky, and he conceals the fact that Simone, a top actress and the star in all his movies, does not exist in reality; she is virtually modeled by the computer program 'Simulation One'. In a situation with a meeting, he intentionally uses stereotypical 'small talk' with relevant speechorganizing markers. This gives him an excuse for leaving the conference room and additional time, which he needs to make his plan work. 
As this extract is rather long, I will analyze it in parts. Consider examples 8-10.

(8) VIKTOR: I can't tell you how delighted I am to have this wonderful cast assembled for "Eternity Forever". Thank you all. Now, a reminder - as a condition for working on this film, you will not be rehearsing with Simone, shooting with Simone and you are forbidden from contacting Simone in any way at any time, whatsoever.

The CAST nods seriously. [...]

VIKTOR (addressing the entire cast): I want you to know, Simone appreciates you all working for scale. But why am I thanking you? Simone can thank you herself. She insisted on speaking with you before filming begins. She's on the line now.

Viktor nods to a speaker phone in the center of the table, a red blinking light on the phone. The cast reacts excitedly.

VIKTOR (pushing a button on the phone): Simone, are you there?

SIMONE (through the speakerphone): I certainly am, Mr. Taransky.

LOTUS (unable to contain her excitement): So are we, Simone!

Everyone laughs giddily.

SIMONE (O.S.): Why don't you leave me alone with my co-stars, Mr. Taransky, so we can get to know each other better?

HAL: Good idea.

VIKTOR: Of course. I'll be back in a minute.

Viktor exits. ("S1mOne")

Example 8 demonstrates the use of encouraging compliments (I can't tell you how delighted I am to have this wonderful cast assembled for "Eternity Forever"; Simone appreciates you all working for scale) and expressions of gratitude (Thank you all; But why am I thanking you? Simone can thank you herself) to please the interlocutors before coming up with the rules of working on this film. Then, he shifts the attention of the cast from prohibitions to Simone's call. Contact-terminating markers are realized via 'a hint to leave', expressed by an interrogative (Why don't you leave me alone with my co-stars, Mr. Taransky, so we can get to know each other better?) and a promise (I'll be back in a minute). 
(9) SIMONE (O.S.): Hi. Who's there? Don't be shy. Introduce yourselves.

The CAST stares nervously at the speakerphone.

MAC: I'm Mac. I turned down a Bertolucci film to be here.

LOTUS: My name's Lotus. God, I can't believe I'm talking to you. We're going to become such great friends.

HAL: I'm Hal. Wonderful to be working together... again.

The other cast members introduce themselves. [...]. VIKTOR races across the vast, empty space to a digital player, connected to a phone. Simone's pre-recorded opening remarks (graphically represented on the screen) are almost completed.

SIMONE: Is that everyone...? (pause) Well, obviously, as you know...

Viktor jumps into the conversation in the nick of time's peaking through the synthesizer. As usual, Viktor's voice is automatically synthesized into the voice of Simone.

SIMONE / VIKTOR: ... I'm Simone.

The other CAST MEMBERS laugh nervously.

HAL (from Viktor's speakerphone): Obviously. Who else? ("S1mOne")

Example 9 shows how a manipulator can intentionally use stereotypical socially regulated situations, which refer to metacommunicative markers (introductions, 'small talk' etc.) for their own purposes. The introduction process starts with an encouragingcontact provoking interrogative (Who's there?) and imperatives (Don't be shy. Introduce yourselves). Contact-establishing markers are partially concealed here, though they can easily be reproduced, as they are traditional clichés (see how Mac, Loutus, and Hal introduce themselves) and are known to everyone.

(10) SIMONE / VIKTOR (from speaker phone): I just want to start by apologizing for my "process" -

The CAST are hunched over the speakerphone.

MAC: No. No. I'm completely simpatico. On my last film I was playing a schizophrenic so I made them give me two dressing rooms.

HAL (an aside): So committed. 
SIMONE (O.S.): Well, thank you for your understanding. I know it's an unusual way to work but I just find I relate better to people when they're not actually there.

LOTUS: Of course, of course.

SIMONE (O.S.): I don't have much to say except that I know it's going to be a great project, if we all just trust Mr. Taransky's vision. Always do what Mr. Taransky says. If in doubt, do it the Taransky way.

They all nod vigorously in agreement.

SIMONE (O.S.): I know we're going to make a wonderful movie together.

LOTUS: (nodding in agreement) Wonderful movie.

HAL: Together, absolutely. ("S1mOne")

Example 10 illustrates the speaker's excessive use of contact-establishing and contactmaintaining markers. Simone (i.e. Victor in reality) turns to excuses (I just want to start by apologizing for my "process"; it's an unusual way to work but...) and gratitudes (thank you for your understanding). Mac's remark (No. No. I'm completely simpatico) is reactive, proving that contact is being maintained. The use of markers and metacommunicative devices of other types, not discussed here (I don't have much to say except that I know; If in doubt), introduce Victor's main requirement, i.e., to follow all his demands, which he cannot say as himself, but can do so, working undercover as Simone. Victor terminates speech contact, inspiring the cast to work productively together.

Approximate designation devices (in terms of Pigrova (Пигрова 2001) express inexactness and vagueness, when the speaker has to break Grice (1975) interaction postulates, in accordance with which he has to speak clearly. It does not mean that the speaker does not want to follow cooperative principles; on the contrary, he seems to be asking to be excused for irregularities. To illustrate this, please refer to Jeremy's words in example 1: "Actually ... we're about to leave", which can be viewed as an excuse for not being very polite in his desire to avoid contact and conversation with the family of Secretary Cleary. Markers of approximate nomination are popular in manipulative 
discourse, when it is necessary to (i) avoid a straightforward answer, distract attention, while maintaining a positive relationship with the interlocutor; and to (ii) gain extra time when mulling over the answer, as shown in example 11:

(11) She starts kissing him. He moves her off his lap.

JEREMY: Gloria, look, I'm tired. It's been a long day. Not to mention [...]. I'm not exactly in the mood.

GLORIA: Fine. ("The wedding crashers")

Example 11 does not reflect the whole situation, only the part where Jeremy attempts to avoid Gloria. First, he starts with excuses and an explanation of the reasons why he cannot follow her desires; then he ends with a marker of approximate nomination (see underscored elements).

Interaction-regulating markers are used to regulate the content of the dialogue (Арюхина 2006; Гнезділова 2014а; Кожинова 2011) and convey the following:

a) imposition or direct / indirect appeals (e.g., to all within the sound of my voice, I appeal; but please bear with me);

b) attracting an interlocutor's attention (e.g., that is indeed something on which to pride yourself; but the world is quite eager to give you ...; by God's grace);

c) degree or measurement (e.g., by any conventional measure; by every usual standard; fail on the scale I did; one of the greatest formative experiences of my life; one of the many things I learned at the end of; with all our hearts; deep down; to the extent that); d) emotions, feelings, and desires; additionally, these markers may introduce or clarify emotions expressed by the head act (e.g., I have wracked my mind and heart for; what I feared most for myself at your age; they would stir our hearts profoundly; I felt a deep urge to; they jar our memory, they touch our hearts; their desire is to help; their desire is to enkindle in us the courage to; feel the sentiments expressed in the words); e) incompleteness (e.g., in part), or contrast, reporting on a narrow outlook or indifference (e.g., never troubling to wonder how it would; choosing to live in narrow spaces leads to); 
f) sincerity (e.g., great; to be sincere; frankly);

g) reassuring (e.g., was truly above; I personally will defend the value of bedtime stories to my last gasp; to be sure; seriously);

h) confirmations (e.g., Indeed; Of course; Yes), specifications (e.g., Actually; in parenthesis; in which case; in search of something I could not then define), explanations (e.g., for this very reason; this is the same reason why I have come here today);

i) enhancing the effect of the aforementioned (e.g., what is more; it is impossible to live without; ever after; those who had disappeared without trace; he speaks in the name of; above all);

j) concessions (e.g., anyhow; in any case);

k) denials (e.g., No -; no other way; but that is not wholly so), emphasizing the termination of something (e.g., I stopped pretending to myself that);

1) generalizing (e.g., for all that; in a much broader sense; in general; when all is said and done; everything else);

m) abstracting, or going beyond something (e.g., beyond anyone's total control);

n) comparison (e.g., unlike any other creature on this planet; like John Paul II);

o) impossibility (e.g., almost impossible; it was impossible for me not to come here as), exceptions (e.g., except that);

p) emphasizing the difficulties (e.g., and it is particularly difficult and troubling for);

q) contingency of words / actions (e.g., incidentally).

The specific features of interaction-regulating metalanguage markers in manipulative discourse are not only in the accentuating particular words / phrases / facts / thoughts, but also in providing additional meanings, hidden evaluation / imposition in accordance with the function performed by a particular metacommunicative device, as shown in example 12:

(12) Suddenly, HAL SINCLAIR, rushes over and hugs Viktor.

HAL: Viktor, I'm so happy for us!

VIKTOR: Hello, Hal. 
HAL: The film. The chemistry. No reflections on Nicola but Simone and I-we were just so right together.

VIKTOR: You never were together, Hal.

HAL: And still the connection was undeniable. (aside) I haven't read "Eternity Forever" but I know it's brilliant. And I know I would be perfect for Clive.

VIKTOR (correcting him): Clyde.

HAL: Yes, perfect. (lowering his voice) As a matter of fact, I ran into Simone on the lot the other day.

VIKTOR (genuinely startled): Really? She didn't mention it.

HAL (quickly covering): I'm sure she's meeting with a lot of people right now. (under his breath) She is just as you described her, Viktor... indescribable. I strongly sensed she thought I was right for it.

Behind his back, Viktor surreptitiously presses a button on his cell phone. The phone rings. Viktor feigns surprise and answers.

VIKTOR (answering the phone he has just dialed, louder than necessary) Hello?... SIMONE! How are you, sweetheart?

A hush descends over the executives. Hal is suddenly very uncomfortable. [...].

VIKTOR (winking to Hal): You'll never guess who I'm with...you ran into him on the lot.

HAL: It was more in passing.

VIKTOR: You're so far off! (finally chuckles) Hal... Hal Sinclair... your co-star. Remember now?... No, I don't think he's put on weight. (a shrug of apology to the appalled Hal) Anyway, you think he's right for "Eternity Forever"?... not the right type?... a different direction...(covering phone, to Hal) I'll try to talk her into it.

The other INDUSTRY PEOPLE make a note of the remark. A mortified Hal excuses himself with a pathetic wave, climbing into his car.

VIKTOR (into phone): ... Listen this is a bad place to talk... what?... sweetheart, I know you have charity work you want to do, I know you want to give back - but remember, your greatest gift is your talent... we'll talk about it at the beach house this weekend... I'm looking forward to it too. 
Viktor hangs up. His car pulls up. ("S1mOne")

Example 12 depicts a situation of 'mutual' manipulation: first, Hal tries to manipulate Victor and get the leading role in his film. Starting with contact-establishing markers (I'm so happy for us), Hal emphasizes his message with additional reassurances (just so right; I'm sure; I strongly sensed), confirmations (Yes, perfect), explanations (As a matter of fact), and comparisons (just as you described her). Being unsuccessful, Hal becomes a victim, and Victor becomes a manipulator; Victor doubts Hal's words (Really?) and makes a false phone call to Simone, thus creating a background for their close relationships. He also starts with contact markers (Hello? How are you, sweetheart?), and continues with the intriguing "You'll never guess who I'm with", ironically denying Simone's inference (No, I don't think he's put on weight). He rounds up with the concessive particle anyway. Beside markers-regulators, Victor actively uses metacommunicative interrogatives (Remember now? what?), imperatives (Listen; but remember), and metatextual markers, which are analyzed below.

\subsubsection{Metatextual markers}

Metatextual markers are used to mark the boundaries of the communicative blocks of discourse. Though optional, they make the text coherent (Гнездилова 2014a; Пигрова 2001), and perform "enumerative, summative, reformulatory, replacive or discoursetransitional functions" (Hübler \& Busse 2012: 3). As discourse organizers, metatextual markers carry out the following functions:

1) express frequency of an action (e.g., every day; yet proven a thousand times every day of our lives; So many times!);

2) show the sequence of actions / thoughts (e.g., first, second; the first step to; the first thing I would like to say is; I have come up with two answers; I chose my second theme; first of all; first and foremost; then) via (i) parallel connection by means of word substitutes (e.g., in other words; alternatively); (i) adversative connection (e.g., however; in spite of a distinct lack of; I had spent far too long in the coffee bar writing stories, and far too little time at lectures; and yet; thus; thereby; instead; on the contrary); (iii) causative-consecutive connection (e.g., so; and so; thus; and therefore); 
2) indicate (i) temporal relations (e.g., in difficult moments; in the darkest hours; ever; yet; there is an expiry date on; for years; a mere seven years after my; at our graduation; in the end; at moments of deep distress; who in every age - yesterday, today and tomorrow), rendering the present moment of speaking (e.g., now; just now; tonight; in the context of an election year; on this wonderful day; for a moment; and as long as I live; so today; at this hour of our history; at the present hour), the future (e.g., someday; then; and tomorrow) or the past events (e.g., largely unknown a decade ago; less than three months ago; until I cast my mind back to my own graduation; half my lifetime ago; at your age; at the time; afterwards; every day of my working week in my early 20s; twenty-seven years ago, on June 7, 1979); and (ii) space relations in the communicative process (e.g., there in my little office; from behind a closed door; to speak in this place of horror, in this place where...; in a place like this; here in this place; here too; in the immediate neighborhood);

3) summarize the speaker's words (e.g., in conclusion; ultimately; I am nearly finished; I have one last hope for you; with the result that; ultimately; finally; I would like to end with).

The peculiarities of metatextual markers in manipulative discourse lie in the additional accentualization of the meaning, rendered by the head act, as shown in example 12 above.

Example 12 illustrates the usage of a number of metacommunicative devices, including metatextual markers, expressed by an adversative connection (And still), and an indicatation of temporal relations (past: the other day; present: right now; and future: this weekend) and location (You're so far off!; at the beach house). For example, Victor summarizes with the contact terminating device 'I'm looking forward to it too'. Importantly, metacommunicative devices, used in example 12, create a gaming background, rendering false admiration, empathy, understanding, sincerity, and love. 
The position of markers, as stated by Aryukhina (Арюхина 2006) and Pigrova (Пигрова 2001), is also important, as it intensifies the intention or perlocutionary effect of the utterance. Markers can be either in preposition, interposition, or postposition to the head act. Therefore, three types of markers are differentiated:

(i) initial markers, which can be general (mark the beginning of new information, new topic and just inform about the speaker's turn to speak) and special (express the relations between the utterance and the previous context). Initial markers are closely connected to turn-taking, and provide the speaker with some extra time when mulling over the answer, soften the beginning of speech, indicate the type of information which follows, make the discourse coherent due to the Grice's (1975) Relevance Maxim, as in example 13 (see an underscored element):

(13) Claire looks up at John who's looking back at her intently.

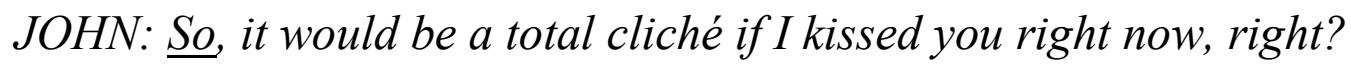

CLAIRE: Yes. A total cliché.

She pulls him in and kisses him. ("The wedding crashers")

(ii) medial markers, whose task is to show that the speaker has not finished speaking, as illustrates example 14 (see underscored elements):

(14) Viktor stops, nods resignedly - suddenly very calm.

VIKTOR: You know what, Nicola, you're right. (picking up her last piece of luggage) Here, let me help you with that. (holding the door for her) You ought to go. The truth is I don't deserve you. This film doesn't deserve you. Frankly, it deserves much, much better. The reason it's not working is because you're not about the work.

Nicola is stunned.

VIKTOR (to the limo driver): To Hell, please.

The door slams and the limo roars away. ("S1mOne")

(iii) final markers, which mark the end of the communicative block and indicate the turn-taking exchange. According to Aryukhina (Арюхина 2006), final markers are rarely used; their function is to intensify propositional modality and intention. Though quantitative analysis of metacommunicative devices was not in the scope of present 
paper, my data shows that final markers are quite frequent in manipulative discourse. Consider the underscored elements in examples 15-16:

(15) JEREMY: I needed to do that, all right?!

JOHN: You needed to do that ... ha. (The wedding crashers: 43)

(16) VIKTOR enters his office where he's greeted by his assistant, JANE.

JANE (sheepish): Thanks for taking me back, Mr. Taransky. I know it looked like I sided with the studio, but I always believed in you, honestly.

VIKTOR: Don't worry. I understand. ("S1mOne")

The position of metatextual markers, realized through anaphoric / cataphoric relations, may be important in manipulative discourse. They serve to create an expressive effect, attract attention, and emphasize words, as illustrated in example 17:

(17) Tonight, I represent an AIDS community whose members have been reluctantly drafted from every segment of American society. Though I am white and a mother, I am one with a black infant struggling with tubes in a Philadelphia hospital. Though I am female and contracted this disease in marriage and enjoy the warm support of my family, I am one with the lonely gay man sheltering a flickering candle from the cold wind of his family's rejection. (Fisher 1992)

Example 17 demonstrates the use of initial metatextual markers. Besides Tonight, the conjunction Though turns metacommunicative due to its anaphoric position (Though I am...I am one with), intensifying the contrast between the main and subordinate clauses. The anaphoric use of though points out and emphasizes the main idea: parallel contradiction in accordance with the stereotypes of society's outlook (white and a mother VS a black infant; female - marriage - family VS lonely man - family's rejection) and the unification of these clauses via the speaker's emphasis on the fact that she breaks the stereotypes and follows her own mind in taboo situations. As a result, she gently manipulates the hearers' consciousness, viewing taboo situations as socially normal. 
I should also consider cases, when similar, but not the same initial markers are used in anaphoric structures. In such a way, they create inciting parallel structures, intensifying the idea of the head act, as shown in example 18:

(18) My call to you, my Party, is to take a public stand, no less compassionate than that of the President and Mrs. Bush. They have embraced me and my family in memorable ways. In the place of judgment, they have shown affection. In difficult moments, they have raised our spirits. In the darkest hours, I have seen them reaching not only to me, but also to my parents, armed with that stunning grief and special grace that comes only to parents who have themselves leaned too long over the bedside of a dying child. (Fisher 1992)

Example 18 illustrates the use of initial metatextual markers of the same structural type, which indicate spacial (In the place of judgment) and temporal relations (In difficult moments; In the darkest hours). Mary Fisher not only informs us about the good deeds of the Bushes, but, by means of these markers and their position, she stresses that the Bushes are able to empathize, understand, and support. In this very way, this US president is being propogandized here.

In sum, it should be pointed out that implicit metacommunicative units or markers, namely metalanguage and metatextual markers, are used as interaction or discourse organizers respectively. In manipulative discourse speech organizers, approximate nomination devices, and interaction regulators as types of metalanguage markers are used to distract the interlocutor's attention. Metatextual markers in manipulative discourse give extra force to that which is rendered by the head act.

\section{Conclusions}

The results of the analyses of metacommunicative units allow me to speak of three groups of metacommunicative units: (i) autonomous and (ii) contextually-dependent metacommunicative units, which are formed synthesizing inner aspects of communication; in comparison to (iii) metacommunicative indicators as genre triggers, 
which detone communicative qualities, imposed from the outside (see Fig. 1 above). The focus of this research is on analyzing autonomous metacommunicative units only.

The group of autonomous metacommunicative units comprises, in my view, all those means (though not purely autonomous), which preserve their metacommunicative functions with a change of context, as opposed to contextually-dependent metacommunicative units, even in cases when other functions dominate. Autonomous metacommunicative units may be in the form of explicit metacommunicative devices or implicit word-combinations and even separate words, known as markers (see Fig. 2 above).

What I want to highlight here is the specifics of use of the aforementioned units in manipulative discourse. This angle of research may demonstrate (i) intentionally increased number of these units; (ii) additional accentuating of the key messages of speech; (iii) layering head acts with additional meaning, including evaluation, imposition etc. I see the reasons for this in the desire of the speaker to hide the true motive of his / her communicative behavior, or to avoid interlocutors' undesirable questions, or distract his / her attention and gain extra time when mulling over the answer, or to impress the interlocutor using all contact-establishing means possible.

Thus, my study is a first step towards understanding that metacommunicative units, being supportive in the utterance, may perform not only 'contacting' and regulating functions, but also become an effective instrument of manipulation. And in future, the study will include the analyses of context-dependent means and metacommunicative indicators as genre triggers in the scope of manipulative discourse. I hope the generalized results may help to develop tips for the 'victims' of manipulation, aimed at the recognition of and resistance to attempts at being manipulated. 


\section{References}

Andrianovna, E.K. (1991). Pragmatic orientation of metacommunicative elements of discourse. In Pragmatic interpretation and planning of discourse. Pyatigorsk: Pyatigorskiy gosudarstvennyi pedadgogicheskiy instityt inostranyx yazykov, p. 15-16. I Andrianovna, E.K. Pragmaticheskaya napravlennost' metakommunikativnyx elementov diskursa. In Pragmaticheskaya interpretatsiya i planirovaniye diskursa. Pyatigorsk: Pyatigorskiy gosudarstvennyi pedagogicheskiy institut inostrannyx yazyikov, p. 15-16. / Андриановна Е.К. Прагматическая направленность метакоммуникативных элементов дискурса. In Прагматическая интерпретация u планирование дискурса. Пятигорск: Пятигорский государственный педагогический институт иностранных языков, с. 15-16.

Archakis, A. (2001). On discourse markers: Evidence from Modern Greek. In Journal of pragmatics, 33(8), p. 1235-1261.

Ariuhina, E.G. (2006). Metacommunicative utterances that control the content side of the dialogue and the intent of utterances. Thesis for the Candidate Degree in Philology, Speciality 10.02.04 - Germanic Languages. University of the Russian Academy of Education. Belgorod. / Ariuhina, E.G. Metakommunikativnyie vyskazyvaniya, upravlyayuschie soderzhatelnoy storonoy dialoga $i$ intentsiey vyiskazyivaniy. Dissertatsiya na soiskaniye uchyenoy stepeni kandidata filolologicheskix nauk. Universitet rossiyskoy akademii obrazovaniya. Belgorod. / Арюхина Е.Г. Метакоммуникативные высказывания, управляющие содержательной стороной диалога и интенщией высказываний / Дис. ... канд. филол. наук / Университет российской академии образования. 10.02.04 - германские языки. Белгород. Available at: http://cheloveknauka.com/metakommunikativnyevyskazyvaniya-upravlyayuschie-soderzhatelnoy-storonoy-dialoga-i-intentsieyvyskazyvaniy\#ixzz2nfFVViT4

Baiat, G.E., Coler, M. et al. (2013). Multimodal analysis of "well" as a discourse marker in conversation: A pilot study. In 4th IEEE international conference on cognitive infocommunications, CogInfoCom 2013; Budapest, 2-5 December 2013. Budapest, Hungary, IEEE, p. 283-288. 
Bogdanova, N.V. (2012). Metacommunication in oral spontaneous speech (dialog vs. monologue). In III International scientific and practical conference "Communication in social and humanitarian knowledge, economics, and education". Minsk, Belarus, March 29-31, p. 330-331. / Bogdanova, N.V. Metakommunikatsiya v ustnoy spontannoy rechi (dialog vs. monolog). In III mezhdunarodnaya nauchnoprakticheskaya konferentsiya "Kommunikatsiya v sotsialno-gumanitarnom znanii, ekonomike, obrazovanii". Minsk, Belarus, 29-31 Marta, s. 330-331. / Богданова Н.В. Метакоммуникация в устной спонтанной речи (диалог vs. монолог). In III международная научно-практическая конференция "Коммуникаџия в социально-гуманитарном знании, экономике, образовании". Минск, Беларусь, 29-31 марта, с. 330-331.

Bogdanova-Beglaryan, N.V. (2014). Pragmatemes in oral everyday speech: Definition of the concept and general typology. In Bulletin of Perm University. Russian and foreign philology, 3(27), p. 7-20. / Bogdanova-Beglaryan, N.V. Pragmatemyi v ustnoy povsednevnoy rechi: opredelenie ponyatiya i obschaya tipologiya. In Vestnik Permskogo universiteta. Rossiyskaya i zarubezhnaya filologiya, Perm, PGNIU, 3(27), s. 7-20. / Богданова-Бегларян Н.В. Прагматемы в устной повседневной речи: определение понятия и общая типология. In Вестник Пермского университета. Российская и заребужная филология, Пермь, ПГНИУ, 3(27), с. 7-20.

Bondarik, E.A. (2011). Metacommunicative meanings of questions in the response position (on the material of Belarusian, Russian and English plays). In Bulletin of Belarusian State University, Series 4: Philology. Journalism. Pedagogy, Minsk, Belorussian State University, 1, p. 52-56. / Bondarik, E.A. Metakommunikativnyie znacheniya voprosov v pozitsii otveta (na materiale belorusskix, russkix i angliyskix pyes). In Vesnik Belaruskaga dzyarzhawnaga universiteta, Seryya 4. FilalogIija. Zhurnalistyka. Pedagogika, Minsk, Belorusskiy gosudarstvennyi universitet, 1, s. 5256. / Бондарик Е.А. Метакоммуникативные значения вопросов в позиции ответа (на материале белорусских, русских и английских пьес). In Веснік Беларускага дзяржаўнага універсітэта. Серыя 4. Філалогія. Журналістыка. Педагогіка, Минск, Белорусский государственный университет, 1, с. 52-56. 
Brock, A. (2012). Historical evidence of communicative maxims. In Investigations into the meta-communicative lexicon of English. A contribution to historical pragmatics. Busse, U. \& Hübler, A. (eds.). Amsterdam-Philadelphia: John Benjamins Publishing Company, p. 271-287.

Bublitz, W. (2012). From speaker and hear to chatter, blogger and user: The changing metacommunicative lexicon in computer-mediated communication. In Investigations into the meta-communicative lexicon of English. A contribution to historical pragmatics. Busse, U. \& Hübler, A. (eds.). Amsterdam-Philadelphia: John Benjamins Publishing Company, p. 151-178.

Cage, J. (1981). Empty words. Middletown, Connecticut, the USA: Wesleyan University Press.

Chkhetiani, T.D. (1987). Linguistic aspects of phatic metacommunication (on the material of the English language). Thesis for the Candidate Degree in Philology, Speciality 10.02.04 - Germanic Languages. Kiev State Pedagogical University of Foreign Languages. Kiev. / Chkhetiani, T.D. Lingvisticheskie aspektyi faticheskoy metakommunikatsii (na materiale angliyskogo yazyika). Dissertatsiya na soiskaniye uchyenoy stepeni kandidata filologicheskix nauk. Kievskiy gosudarstvennyi pedagogicheskiy institut inostrannyx yazykov. Kiev. / Чхетиани Т.Д. Лингвистические аспекты фатической метакоммуникации (на материале английского языка) / Дис. ... канд. филол. наук / Киевский государственный педагогический институт иностранных языков. 10.02.04 - германские языки. Киев.

Chkhetiani, T.D. (1989). Contact-supporting function of metacommunicative questions. In Speech and discourse in the pragmalinguistic aspect. Kiev: Kiev State Pedagogical Institute of Foreign Languages, p. 100-103 / Chkhetiani, T.D. Kontaktopodderzhivayuschaya funktsiya metakommunikativnyx voprosov. In Vyiskazyivanie $i$ diskurs $v$ pragmalingvisticheskom aspekte. Kiev: Kievskiy gosudarstvennyi pedagogicheskiy institut inostrannyix yazykov, s. 100-103 / Чхетиани Т.Д. Контактоподдерживающая функция метакоммуникативных вопросов. In Высказывание и дискурс в прагмалингвистическом аспекте. Киев: 
Киевский государственный педагогический институт иностранных языков, с. 100-103.

Chkhetiani, T.D. (1991). Reflexive metacommunicative question in contact maintaining function. In Pragmatic interpretation and planning of discourse. Pyatigorsk: Pyatigorskiy gosudarstvennyi pedadgogicheskiy instityt inostranyx yazykov, p. 100-102. / Chkhetiani, T.D. Refleksivnyi metakommunikativnyi vopros v funktsii kontaktopodderzhaniya. In Pragmaticheskaya interpretatsiya i planirovaniye diskursa. Pyatigorsk: Pyatigorskiy gosudarstvennyi pedadgogicheskiy institut inostranyx yazykov, p. 100-102. / Чхетиани Т.Д. Рефлексивный метакоммуникативный вопрос в функции контактоподдержания. In Прагматическая интерпретация $u$ планирование дискурса. Пятигорск: Пятигорский государственный педагогический институт иностранных языков, с. $100-102$

Coulthard, M. (1981). An introduction to discourse analysis. Hong Kong: Longman. Croucher, S.M. (2004). Like, You know, What I'm saying: A study of discourse marker frequency in extemporaneous and impromptu speaking. In Fall, p. 38-47. Available at: https://b55eec4b-a-62cb3a1a-s-sites.googlegroups.com/site/nationalforensics association/research/nfa-journal/vol22no2-3.pdf?attachauth=ANoY7cpTcmVNzwg D0gPLWnVZLQr5-NvulpOMhUGfPCixXe7_cW3WCPc-J7rfSK8svbOdlnrxuxt TakYvkLJ4UzjgMa5-pByaYFc7fzuV5ihwu342fBwTDillsgaqUj8CSlyXuv Ef3eeYKy-96EOs2S1irCnsEDkjOLh1UYoxw2sRd0tzWGSvkzuC7gV1qQWtozuGWMG0H zca33keohlUAOUYP KJoWntTuaqujxHaqvCIJNcwi2MLXYEpiUZ UQyjGgqvRo41 01vKJJWQ-0t-5q-JfXi454A\%3D\%3D\&attredirects $=0$

Dossena, M. (2012). "I write you these lines": Metacommunication and pragmatics in $19^{\text {th }}$ century Scottish emmigrants' letters. In Investigations into the metacommunicative lexicon of English. A contribution to historical pragmatics. Busse, U. \& Hübler, A. (eds.). Amsterdam-Philadelphia: John Benjamins Publishing Company, p. 45-63.

Fisher, M. (1992). A Whisper of AIDS. Available at: http:/www.americanrhetoric.com/speeches/maryfisher1992rnc.html 
Fitzmaurice, S. (2012). Sociability: Conversation and the performance of friendship in early eighteenth-century letters. In Investigations into the meta-communicative lexicon of English. A contribution to historical pragmatics. Busse, U. \& Hübler, A. (eds.). Amsterdam-Philadelphia: John Benjamins Publishing Company, p. 21-44.

Foolen, A. (1996). Pragmatic particles. In Handbook of pragmatics. Verschueren, J., Östman, J-O., Blommaert, J., \& Bulcaen, C. (eds.). Amsterdam-Philadelphia: John Benjamins Publ. Co, p. 1-24.

Fox Tree, J. E. (2010). Discourse markers across speakers and settings. In Language and linguistics compass, 3(1), p. 1-13.

Fraser, B. (1993). Discourse markers across language. In Pragmatics and language learning, 4, p. 1-17.

Gnezdilova, Ya.V. (2014a). Cohesion of public metadiscourse. In Scientific journal of International Humanitarian University. Series: Philology, Odesa, Publishing house "Gel'vetyka", 8(2), p. 218-220. / Gnezdilova, Ya.V. Koheziya publichnoho metadyskursu. In Naukovyi visnyk mizhnarodnoho humanitarnoho universytetu. Seriya: Filolohiya, Odesa, Vydavnychyi dim "Gel'vetyka", 8(2), s. 218-220. I Гнезділова Я.В. Когезія публічного метадискурсу. In Науковий вісник міжнародного гуманітарного університету. Серія Філологія, Одеса: Видавничий дім "Гельветика", 8(2), с. 218-220.

Gnezdilova, Ya.V. (2014b). Pragmatics of metacommunicative questions: Emotiological aspect. In Bulletin of KNLU. Series: Philology, Kyiv: KNLU, 17(1), p. 39-45 / Gnezdilova, Ya.V. Prahmatyka metakomunikatyvnyx pytan': emotiolohichnyy aspekt. In Visnyk KNLU. Seriya Filolohiya, Kyiv: KNLU, 17(1), s. 39-45 / Гнезділова Я.В. Прагматика метакомунікативних питань: емотіологічний аспект. In Вісник КНЛУ. Серія Філологія, Київ: КНЛУ, 17(1), с. 39-45.

Gotti, M. Managing disputes with civility: On seventeenth-century argumentative discourse. In Investigations into the meta-communicative lexicon of English. A contribution to historical pragmatics. Busse, U. \& Hübler, A. (eds.). AmsterdamPhiladelphia: John Benjamins Publishing Company, p. 89-110. 
Grice, H.P. (1975). Logic and conversation. In Syntax and semantics. New York: Academic Press, p. 41-58.

Hatch, E. (1994). Discourse and language education. Cambridge: Cambridge University Press.

Hedz, S.F. (1998). Communicative and pragmatic features of interrogative utterances in modern English. Thesis for the Candidate Degree in Philology, Speciality 10.02.04 - Germanic Languages. Kyiv State Pedagogical University of Foreign Languages. Kyiv. / Hedz, S.F. Komunikatyvno-prahmatychni osoblyvosti vyslovlyuvan' $z$ interohatyvnym znachennyam u suchasniy anhliys'kiy movi. Dysertatsiya na zdobuttya vchenoho stupenya kandydata filolohichnyx nauk. Kyivs'kyi derzhavnyi pedahohichnyi instytut inozemnykh mov. Kyiv. / Гедз С.Ф. Комунікативнопрагматичні особливості висловлювань з інтерогативним значенням у сучасній англійській мові / Дис. ... канд. філол. наук / Київський державний педагогічний інститут іноземних мов. 10.02.04 - германські мови. Київ.

Heyd, Th. (2012). The metapragmatics of hoaxing. In Investigations into the metacommunicative lexicon of English. A contribution to historical pragmatics. Busse, U. \& Hübler, A. (eds.). Amsterdam, Philadelphia: John Benjamins Publishing Company, p. $129-150$.

Hrabovs'ka, I.V. (2014). Metakomunikative questions in modern English dialogical discourse: Semantics and pragmatics. Thesis for the Candidate Degree in Philology, Speciality 10.02.04 - Germanic Languages. Kyiv National Linguistic University. Kyiv. / Hrabovs'ka, I.V. Metakomunikatyvni pytannya v suchasnomu anhlomovnomu dialohichnomu dyskursi: semantyka $i$ prahmatyka. Dysertatsiya na zdobuttya vchenoho stupenya kandydata filolohichnyx nauk. Kyivs'kyi natsional'nyi linhvistychnyi universytet. Kyiv. / Грабовська I.В. Метакомунікативні питання в сучасному англомовному діалогічному дискурсі: семантика і прагматика / Дис. ... канд. філол. наук / Київський національний лінгвістичний університет. 10.02 .04 - германські мови. Київ.

Hübler, A. \& Busse, U. (2012). Introduction. In Investigations into the metacommunicative lexicon of English. A contribution to historical pragmatics. Busse, U. 
\& Hübler, A. (eds.). Amsterdam, Philadelphia: John Benjamins Publishing Company, p. 1-16.

Hum, T., R. P., M. \& Hum D., D., M. The Use of ' $O h^{\prime}$ and 'Well' as discourse markers in conversation of Bandung state polytechnic students, p. 762-771. Available at: http://www.litu.tu.ac.th/journal/FLLTCP/Proceeding/762.pdf

Kennedy, G. (1998). An Introduction to corpus linguistics. London, New York: Longman.

Kohnen, Th. Performative and non-performative uses of speech-act verbs in the history of English. In Investigations into the meta-communicative lexicon of English. A contribution to historical pragmatics. Busse, U. \& Hübler, A. (eds.). AmsterdamPhiladelphia: John Benjamins Publishing Company, p. 207-222.

Kozhinova, A.A. (2011). About metacommunication in the psalm text. In Karpov scientific readings, 5(1). Golovnya, A.I. (ed.). Minsk: "Belarusian Press House", p. 3336. / Kozhinova, A.A. O metakommunikatsii v tekste psaltiri. In Karpovskie nauchnyie chteniya, 5(1). Golovnya, A.I. (ed.). Minsk: "Belorusskiy Dom pechati", s. 33-36. / Кожинова А.А. О метакоммуникации в тексте псалтири. In Карповские научные чтения, 5(1). А.И. Головня (отв. ред.). Минск: "Белорусский Дом печати", с. 3336.

Krongauz, M.A. (2001). Text and discourse. In Semantics. Moscow: RGGU, p. 255266. / Krongauz, M.A. Tekst i diskurs. In Semantika. Moskva: RGGU, s. 255-266. / Кронгауз М.А. Текст и дискурс. In Семантика. Москва: РГГУ, с. 255-266.

Krongauz, M.A. (2007). The Russian language on the verge of a nervous breakdown: sign; languages of Slavic cultures. Moscow: LITRES. / Krongauz, M.A. Russkiy yazyik na grani nervnogo sryiva: Znak; Yazyki slavyanskix kultur. Moskva: LITRES. / Кронгауз М.А. Русский язык на грани нервного срыва: знак; языки славянских культур. Москва: LITRES.

Kryvoruchko, S.I. (2011). Linguo-pragmatic properties of perlocutorary optimizers in modern German-speaking discourse. Thesis for the Candidate Degree in Philology, Speciality 10.02.04 - Germanic Languages. V.N. Karazin Kharkiv National University. Kharkiv. / Kryvoruchko, S.I. Linhvoprahmatychni vlastyvosti 
perlokutyvnyx optymizatoriv u suchasnomu nimets'komovnomu dyskursi. Dysertatsiya na zdobuttya vchenoho stupenya kandydata filolohichnyx nauk. Kharkivs'kyi natsional'nyi universytet imeni V.N. Karazina. Kharkiv. / Криворучко C.I. Лінгвопрагматичні властивості перлокутивних оптимізаторів у сучасному німецькомовному дискурсі / Дис. ... канд. філол. наук / Харківський національний університет імені В.Н. Каразіна. 10.02.04 - германські мови. Харків.

Kuo, P. (1994). The correlation of discourse markers and discourse structures. In Pragmatics and language learning, 5, p. 208-230.

Kupryashkina, S.V. (1991). Metaspeech means of organization of dialogical interaction. In Pragmatic interpretation and planning of discourse. Pyatigorsk: Pyatigorskiy gosudarstvennyi pedagogicheskiy instityt inostranyx yazykov, p. 58-59. / Kupryashkina, S.V. Metarechevyie sredstva organizatsii dialogicheskogo vzaimodeystviya. In Prahmaticheskaya interpretatsiya $i$ planirovaniye diskursa. Pyatigorsk: Pyatigorskiy gosudarstvennyi pedagogicheskiy institut inostrannyx yazyikov, p. 58-59. / Купряшкина С.В. Метаречевые средства организации диалогического взаимодействия. In Прагматическая интерпретация $u$ планирование дискурса. Пятигорск: Пятигорский государственный педагогический институт иностранных языков, с. 58-59.

Ladyzhenskaya, B.Ya. (1985). Specifics of the organization of oral spontaneous speech (parenthetic elements in speech). Thesis for the Candidate Degree in Philology, Speciality 10.02.01 - Russian Language. Moscow State University. Moscow. I Ladyizhenskaya, B.Ya. Osobennosti organizatsii ustnoy spontannoy rechi (vstavnyie elementyi $v$ rechevom potoke). Dissertatsiya na soiskaniye uchyenoy stepeni kandidata filologicheskix nauk. Moskovskiy gosudarstvennyi universitet. Moskva. / Ладыженская Б.Я. Особенности организащии устной спонтанной речи (вставные элементы в речевом потоке) / Дис. ... канд. филол. наук / Московский государственный университет. 10.02.01 - русский язык. Москва.

Lenk, S. (1998). Discourse markers and global coherence in conversation. In Journal of pragmatics, 30(4), p. 245-257. 
López Álvarez, E. (2005). Performative speech act verbs in present day English. In Interlingüística, 16(2), p. 685-702.

Maliuga, E.N. (2001). Functional and pragmatic aspects of English interrogative sentences. Moscow: MAX Press. / Maliuga, E.N. Funktsionalno-pragmaticheskie aspektyi angliyskix voprositelnyix predlozheniy. Moskva: MAKS Press. / Малюга Е.Н. Функционально-прагматические аспекты английских вопросительных предложений. Москва: МАКС Пресс.

Matiukhina, Yu.V. (2004). The development of the system of phatic metacommunication in the English discourse of the 16th-20th centuries. Thesis for the Candidate Degree in Philology, Speciality 10.02.04 - Germanic Languages. V.N. Karazin Kharkov National University. Kharkov. / Matiuhina, Yu.V. Razvitie sistemyi faticheskoy metakommunikatsii $v$ angliyskom diskurse 16-20 vv. Dissertatsiya na soiskaniye uchyenoy stepeni kandidata filologicheskix nauk. Kharkovskiy natsionalnyi universitet imeni V.N. Karazina. 10.02.04 - germanskie yazyiki. Kharkov. / Матюхина Ю.В. Развитие системь фатической метакоммуникации в английском дискурсе 16-20 вв. / Дисс. ... канд. филол. наук / Харковский национальный университет имени В.Н. Каразина. 10.02.04 - германские языки. Харьков.

Navarretta, C. (2015). The functions of fillers, filled pauses and co-occurring gestures in Danish dyadic conversations. In Proceedings from the 3rd European symposium on multimodal communication, Dublin, Ireland, September, 17-18, 2015, p. 55-61.

Pigrova, E.K. (2001). Metacommunicative markers in oral spontaneous speech. Thesis for the Candidate Degree in Philology, Speciality 10.02.01 - Russian Language. Saint Petersburg University. Saint Petersburg. / Pigrova, E.K. Metakommunikativnyie markeryi $v$ ustnoy spontannoy rechi. Dissertatsiya na soiskaniye uchyenoy stepeni kandidata filolologicheskix nauk. Sankt-Peterburgskiy gosudarstvennyi universitet. Sankt Petersburg. / Пигрова Е.К. Метакоммуникативные маркеры в устной спонтанной речи / Дис. ... канд. филол. наук / Санкт-Петербургский государственный университет. 10.02.01 - русский язык. Санкт-Петербург. 
Available at: http://cheloveknauka.com/metakommunikativnye-markery-v-ustnoyspontannoy-rechi\#ixzz2nfA0rSXp

Pope Benedict XVI (2006). In this place of honor. Available at: http://www.historyplace.com/speeches/pope-benedict-auschwitz.htm

Risselada, R. (1998). Introduction: discourse markers and coherence relations. In Journal of pragmatics, 30(2), p. 131-133.

Rowling, J.K. (2008.) The fringe benefits of failure, and the importance of imagination.

Available at: http://news.harvard.edu/gazette/story/2008/06/text-of-j-k-rowling$\underline{\text { speech/ }}$

Ruth, R. (2001). Turns and hearers signals. In Linguistics of text and conversation. von Brinker, K. (ed.). Walter de Gruyter, p. 1213-1226.

SlmOne (2002). Available at: $\underline{\text { https://sfy.ru/?script=s1m0ne }}$

Schiffrin, D. (1996). Discourse markers. Cambridge: Cambridge University Press.

Simon-Vanderbergen, A.-M. \& Defour, T. (2012). Verbs of answering revisited: A corpus-based study of their pragmatic development. In Investigations into the metacommunicative lexicon of English. A contribution to historical pragmatics. Busse, U. \& Hübler, A. (eds.). Amsterdam-Philadelphia: John Benjamins Publishing Company, p. 223-246.

Sinitsyna, A.N. (2005). Metacommunication units and their role in the organization and regulation of English-speaking dialogic communication. Thesis for the Candidate Degree in Philology, Speciality 10.02.04 - Germanic Languages. Saint Petersburg: Saint Petersburg University. / Sinitsyina, A.N. Metakommunikativnyie edinitsyi i ih rol $v$ organizatsii $i$ regulyatsii angloyazyichnogo dialogicheskogo obscheniya. Dissertatsiya na soiskaniye uchyenoy stepeni kandidata filolologicheskix nauk. SanktPeterburg: Sankt-Peterburgskiy gosudarstvennyi universitet. / Синицына А.Н. Метакоммуникативные единищь и их роль в организаџии и регулящии англоязычного диалогического общения / Дис. ... канд. филол. наук. СанктПетербург: Санкт-Петербургский государственный университет. 10.02 .04 германские языки. Санкт-Петербург.

Available at: 
http://cheloveknauka.com/metakommunikativnye-edinitsy-i-ih-rol-v-organizatsii-iregulyatsii-angloyazychnogo-dialogicheskogo-obscheniya\#ixzz2nfFuIIfM

Strelchenko, N.S. (2016). Echo questions in English dialogical discourse. Thesis for the Candidate Degree in Philology, Speciality 10.02.04 - Germanic Languages. Kyiv: National Linguistic University. / Strel'chenko, N.S. Pytannya-perepyty $v$ anhlomovnomu dialohichnomu dyskursi. Dysertatsiya na zdobuttya vchenoho stupenya kandydata filolohichnyx nauk. Kyiv: Kyivs'kyi natsional'nyi linhvistychnyi universytet. / Стрельченко Н.С. Питання-перепити в англомовному діалогічному дискурсі / Дис. ... канд. філол. наук / Київ: Київський національний лінгвістичний університет. 10.02.04 - германські мови.

Taavitsainen, I. \& Hiltunen, T. (2012). Now as a text deictic feature in late medieval and early modern English medical writing. In Investigations into the metacommunicative lexicon of English. A contribution to historical pragmatics. Busse, U. \& Hübler, A. (eds.). Amsterdam-Philadelphia: John Benjamins Publishing Company, p. $179-208$.

The Big Bang Theory (2007). Available at: https://bigbangtrans.wordpress.com/series1-episode-1-pilot-episode/

The Wedding Crashers (2005). Available at: http://www.dailyscript.com/scripts/ wedding_crashers.pdf

Torres, L. (2002). Bilingual discourse markers in Puerto Rican Spanish. In Language in society, 31(1), p. 65-83.

Ushchyna, V.A. (2015). Stancetaking in contemporary English risk discourse: Sociocognitive aspect. Lutsk: Vezha-Druk / Ushchyna, V.A. Pozytsionuvannya sub'yekta v anhlomovnomu dyskursi ryzyku: sotsiokohnityvnyy avpekt. Luts'k: VezhaDruk / Ущина B.А. Позиціонування суб'єкта в англомовному дискурсі ризику: соціокогнітивний аспект. Луцьк: Вежа-Друк.

Verschueren, J. (2012). The metapragmatics of civilized belligerence. In Investigations into the meta-communicative lexicon of English. A contribution to historical pragmatics. Busse, U. \& Hübler, A. (eds.). Amsterdam-Philadelphia: John Benjamins Publishing Company, p. 111-128. 
Volkova, L.M. (1987). Semantics and pragmatics of particles in modern English (on the basis of particles with a temporal meaning). Thesis for the Candidate Degree in Philology, Speciality 10.02.04 - Germanic Languages. Kiev: Kiev State Pedagogical University of Foreign Languages. / Volkova, L.M. Semantika i pragmatika chastits $v$ sovremennom angliyskom yazyike (na materiale chastits so znacheniem temporalnosti). Dissertatsiya na soiskaniye uchyenoy stepeni kandidata filologicheskix nauk. Kiev: Kievskiy gosudarstvennyi pedagogicheskiy institut inostrannyix yazyikov. / Волкова Л.М. Семантика и прагматика частии в современном английском языке (на материале частии со значением темпоральности) / Дис. ... канд. филол. наук / Киев: Киевский государственный педагогический институт иностранных языков. 10.02.04 - германские языки.

Wierzbicka, A. (1978). Metatext in text. In New in foreign linguistics, IX. Text linguistics, p. 402-421. / Vezhbitska, A. Metatekst v tekste. In Novoye v zarubezhnoy lingvistike, IX. Lingvistika teksta, s. 402-421. / Вежбицка А. Метатекст в тексте. In Новое в зарубежной лингвистике, IX. Лингвистика текста, с. 402-421.

Yang, Yi. \& Wilbur, W. J. (1996). Using corpus statistics to remove redundant words in text categorization. In Journal of the American society for information science, 47(5), p. 357-369.

Yuan, J., Xu, X. et al. (2016). Pauses and pause fillers in mandarin monologue speech: the effects of sex and proficiency. Available at: https://www.ldc.upenn.edu/sites/ www.ldc.upenn.edu/files/speechprosody2016-pauses-fillers-mandarin.pdf

Zarei, F. (2013). Discourse markers in English. In International research journal of applied and basic sciences, 4 (1), p. 107-117.

Zasiekin, S.V. (2001). Discourse markers of coherence in English dialogue text: Cognitive and pragmatic aspects. Thesis for the Candidate Degree in Philology, Speciality 10.02.04 - Germanic Languages. Kyiv: National Linguistic University. I Zasiekin, S.V. Dyskursyvni markery koherentnosti anhlomovnoho dialohichnoho tekstu: kohnityvnyi ta prahmatychnyi aspekty. Dysertatsiya na zdobuttya vchenoho stupenya kandydata filolohichnyx nauk. Kyiv: Kyivs'kiy natsional'nyi linhvistychnyi universytet. / Засєкін С.В. Дискурсивні маркери когерентності англомовного 
діалогічного тексту: когнітивний та прагматичний аспекти / Дис. ... канд. філол. наук / Київ: Київський національний лінгвістичний університет. 10.02.04 - германські мови.

Zemskaya, E.A. (1983). Russian ceremonial speech: Phonetics, morphology, vocabulary, gesture. Moscow: Science / Zemskaya, E.A. Russkaya razgovornaya rech: fonetika, morfologiya, leksika, zhest. Moskva: Nauka / Земская Е.А. Русская разговорная речь: фонетика, морфология, лексика, жест. Москва: Наука.

Zernetskiy, P.V. (1992). Speech communication in English (Communicative and functional aspect of discourse). Kiev: Lybid' / Zernetskiy, P.V. Rechevoe obschenie na angliyskom yazyke (Kommunikativno-funktsionalny aspekt diskursa). Kiev: Lyibid' / Зернецкий П.В. Речевое общение на английском языке (Коммуникативнофункциональный аспект дискурса). Киев: Лыбидь.

\begin{tabular}{|l|l|l|}
\hline $\begin{array}{c}\text { Contact data } \\
\text { Yaroslava Gnezdilova } \\
\text { CSc. (Philology) } \\
\text { Assistant Professor, } \\
\text { Postdoctoral student at the } \\
\text { Department of German and } \\
\text { Finno-Ugrian Philology, Kyiv } \\
\text { National Linguistic University, } \\
\text { Velyka Vasylkivska, 73, Kyiv, } \\
\text { 03680, Ukraine e-mail: } \\
\text { yaroslava.gn@gmail.com }\end{array}$ & $\begin{array}{l}\text { Fields of interest } \\
\text { Pragmatics, discourse } \\
\text { studies, rhetoric, } \\
\text { public communication, } \\
\text { speech manipulation, } \\
\text { emotiology, grammar. }\end{array}$ \\
\hline
\end{tabular}

\section{Résumé in English}

This article focuses on the study of metacommunicative means. A unified approach to their classification is based on an assumption of the metapragmatic awareness of people. The author differentiates three groups of metacommunicative units, giving special attention to distinguishing the basic types of autonomous metacommunicative means and their functioning in manipulative discourse. The results show that the group of autonomous metacommunicative units comprises all those means which do not lose 
their metacommunicative functions with a change of the context. The aforementioned units may be in the form of explicit metacommunicative devices (i.e. declaratives, imperatives and interrogatives) or implicit word-combinations / words, known as markers (i.e. metalanguage and metatextual markers). The analysis of these devices in manipulative discourse allowed the author to discover that autonomous metacommunicative units, being supportive in the utterance, may perform not only 'contacting' and regulating functions, but also become effective instruments of manipulation. Explicit metacommunicative devices, especially interrogatives, the metacommunicative nature of which is by now self-evident, are used to encourage, impose, or incite the interlocutor to some particular behavior desirable to the speaker. They happen to be a valuable tool used to intensify the perlocutionary effect of the utterance as well as metatextual markers that, being 'structure-oriented', are responsible for discourse cohesion and coherence. On the contrary, metalanguage markers, being 'content-oriented', i.e. organizing and regulating interaction / speech in accordance with Grice interaction postulates, are used by the speaker to distract the interlocutor's attention and to conceal the true motive from the hearer while pursuing his/her own interests.

Key words: metacommunication, metadiscourse, metacommunicative means, explicit / implicit metacommunicative devices, metalanguage / metatextual markers, manipulative discourse.

\section{Résumé in German (translated by Oksana Zinchenko)}

Dieser Artikel ist der Untersuchung von metakomunnikativen Mitteln und der Feststellung einheitlichen Ansatzes zu ihrer Klassifizierung auf Grund menschlicher metapragmatischer Kompetenz gewidmet. In diesem Zusammenhang werden drei Gruppen von Metakommunikativen unterschieden. Besondere Aufmerksamkeit wird nur auf Demarkation von Haupttypen autonomer Metakommunikativen und ihrer Funktion im manipulativen Diskurs gelenkt. Laut der Ergebnissen der Untersuchung fasst die Gruppe autonomer Metakommunikativen alle Mittel um, die ihre 
metakommunikativen Funktionen bei der Veränderung des Kontextes bewahren. Obengenannte Mittel sind durch explizite metakommunikative Mittel (Deklarativen, Imperativen und Interrogativen) und implizite Wortverbindungen, die als Marker (metasprachliche und textgemäße Marker) gelten, vertreten. Analyse dieser Mittel im manipulativen Diskurs erlaubte solche Schlussfolgerungen zu ziehen, dass autonome Metakommunikativen als Hilfsmittel in der Aussage nicht nur Verbindungsfunktion und Ordnungsfunktion erfüllen, sondern auch als effektives Instrument der Manipulation auftreten. Explizite metakommunikative Mittel, besonders Metakommunikativen, deren metakommunikative Natur heutzutage offensichtlich ist, werden gebraucht, um den Gesprächspartner zu ermutigen, dem Gesprächspartner ein Verhalten aufzudrängen oder ihn dazu zu provozieren, was dem Sprecher nötig ist. Sie sind ein wertvolles Mittel, das für die Verstärkung perlokutiver Wirkung der Aussage gebraucht wird. In dieser Funktion werden auch metatextuale Marker gebraucht, die als strukturell-orientierte Einheiten für Kohärenz und Unteilbarkeit des Diskurses verantwortlich sind. Metasprachliche Marker sind im Gegenteil für den Inhalt verantwortlich. Das bedeutet, dass sie Interaktion nach interaktiven Grundvoraussetzungen von Grice organisieren und ordnen und werden von dem Sprecher benutzt, der seine Zwecke verfolgt, um die Aufmerksamkeit des Gesprächspartners abzulenken oder wirkliches Motiv von dem Gesprächspartner zu verbergen.

Stichwörter: Metakommunikation, Metadiskurs, Metakommunikativen, explizite/implizite metakommunikative Mittel, metasprachliche/metatextuale Marker, manipulativer Diskurs.

\section{Résumé in French (translated by Olena Vlokh)}

Le présent article porte sur l'étude des moyens métacommunicatifs et la recherche d'une approche unifiée de leur classification basée sur la compétence métapragmatique des individus (ang. awareness). L'auteure distingue trois classes de métacommunicatifs, mais attache une attention particulière surtout sur les types 
essentiels de métacommunicatifs autonomes et leur fonctionnement dans le discours manipulateur. Les résultats de son analyse démontrent que les métacommunicatifs autonomes embrassent tous les moyens dont les fonctions métacommunicatives ne changent pas suite au changement de contexte. Parmi ces moyens, on trouve des métacommunicatifs explicites dont les déclaratifs, impératifs et interrogatifs ainsi que des expressions implicites dites marqueurs métalinguistiques ou métacontextuels. L'analyse du fonctionnement de ces moyens dans le discours manipulateur permet de conclure que les métacommunicatifs autonomes peuvent remplir non seulement une fonction de contact, une fonction régulatrice, mais aussi servent d'un instrument efficace de manipulation. Les métacommunicatifs explicites, notamment les interrogatifs dont la nature est actuellement évidente sont employés pour inspirer, imposer ou provoquer chez l'autre le comportement que son interlocuteur attend de lui. Ce sont des moyens importants susceptibles de renforcer l'effet perlocutif du discours, tout comme les marqueurs métacontextuels qui, tout en étant des éléments structurels, assurent la cohésion et la cohérence du discours. Les marqueurs métalinguistiques portent, au contraire, sur le contenu car ils organisent et régissent l'intercation en fonction des postulats interactifs définis par Grice et sont employés pour détourner l'attention de l'interlocuteur et lui dissimuler la vraie intension du message.

Mots-clés: métacommunication, métadiscours, métacommunicatifs, moyens métacommunicatifs explicites / implicites, marqueurs métalinguistiques/ métacontextuels, dicours manipulateur.

\section{Résumé in Russian}

Статья посвящена изучению метакоммуникативных средств и выделению унифицированного подхода к их классификации, исходя из метапрагматической компетентности людей. Автор выделяет три группы метакоммуникативов, но особое внимание обращается на разграничение основных типов только автономных метакоммуникативов и их функционирование в манипулятивном дискурсе. Результаты анализа показывают, что группа автономных 
метакоммуникативов охватывает все те средства, которые сохраняют свои метакоммуникативные функции при изменении контекста. Вышеуказанные средства представлены эксплицитными метакоммуникативными средствами (т.е. декларативами, императивами и интеррогативами), и имплицитными словосочетаниями / словами, известными как маркеры (т.е. метаязыковые и метатекстуальные маркеры). Анализ этих средств в манипулятивном дискурсе позволил сделать вывод, что автономные метакоммуникативы как вспомогательные в высказывании могут выполнять не только "контактную" и регулирующую функции, но и выступают эффективным инструментом манипуляции. Эксплицитные метакоммуникативные средства, особенно интеррогативы, метакоммуникативная природа которых на сегодняшний день является очевидной, используются, чтобы воодушевить, навязать или спровоцировать собеседника на определённое поведение, так необходимое говорящему. Они являются ценным средством, используемым для усиления перлокутивного эффекта высказывания, так же как и метатекстуальные маркеры, которые как структурно-ориентированные единицы отвечают за связность и целостность дискурса. Метаязыковые маркеры наоборот отвечают за содержание, т.е. организовывают и регулируют интеракцию / речь в соответствии с интерактивными постулатами Грайса, и используются говорящим, преследующим свои цели, для отвлечения внимания собеседника или сокрытия истинного мотива от слушателя.

Ключевые слова: метакоммуникация, метадискурс, метакоммуникативы, эксплицитные / имплицитные метакоммуникативные средства, метаязыковые / метатекстуальные маркеры, манипулятивный дискурс.

Article was received by the editorial board 23.03.17;

Reviewed 08.05.17. and 21.05.17.

Similarity Index 29\%. 